\title{
McCarthyism and the Mathematization of Economics
}

Roy Weintraub

Duke University

February 18, 2016

ERID Working Paper Number 209

This paper can be downloaded without charge from the Social Science Research Network Electronic Paper Collection:

http://ssrn.com/abstract=2737050

Economic Research Initiatives at Duke WORKING PAPERS SERIES

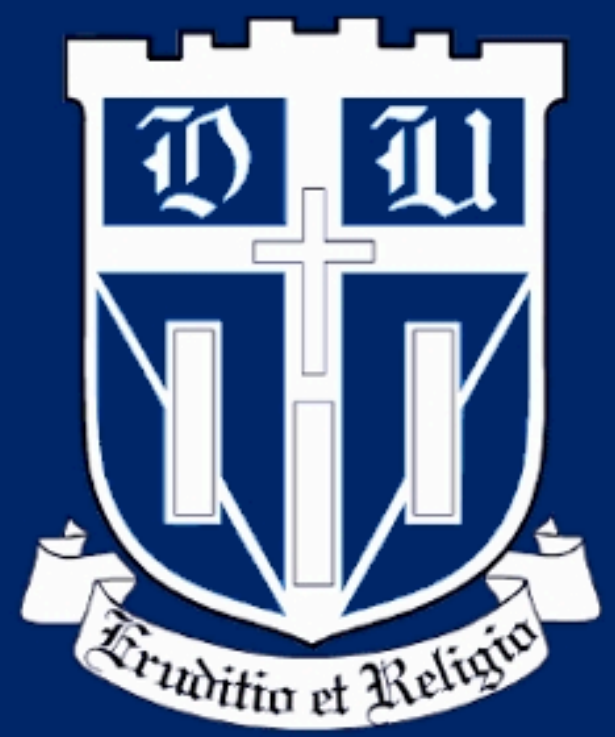




\section{ABSTRACT \\ McCarthyism and the Mathematization of Economics \\ By E. Roy Weintraub, Duke University}

Historians of the social sciences and historians of economics have come to agree that, in the United States, the 1940s transformation of economics from political economy to economic science was associated with economists' engagements with other disciplines - e.g. mathematics, statistics, operations research, physics, engineering, cybernetics - during and immediately after World War II. More controversially, some historians have also argued that the transformation was accelerated by economists' desires to be safe, to seek the protective coloration of mathematics and statistics, during the McCarthy period. This paper argues that that particular claim 1) is generally accepted, but 2) is unsupported by good evidence, and 3) what evidence there is suggests that the claim is false.

JEL Codes: B2, B4, B5, C02, C10, C60

Key Words: Cold War, McCarthyism, mathematical economics, mathematization of economics, history of philosophy, RAND, Cowles Commission, Paul Lazarsfeld 


\title{
McCarthyism and the Mathematization of Economics ${ }^{1}$ \\ By E. Roy Weintraub, Duke University
}

(Version: February 19, 2016)

\begin{abstract}
"It isn't what you don't know that will get you into trouble,
it's what you know that isn't true."

(Attributed to Will Rogers, or Josh Billings, among others)
\end{abstract}

\section{Introduction}

The 1999 HOPE conference directed by Mary Morgan and Malcolm Rutherford changed how historians of economics, and historians of other social sciences, thought about the development of economics in the twentieth century. The various essays in their conference volume, From Interwar Pluralism to Postwar Neoclassicism (1999), told a new story of the transformation of economics after World War II. The older view that it supplanted was that, in the American case, institutionalism had been the dominant professional practice, and that over the 1940s and 50s into the 1960s it was replaced by neoclassical economics. The various essays in the Morgan-Rutherford volume present a quite different picture, namely one in which a rich and varied set of conversations and approaches came to be replaced by a single mainstream with marginalized heterodox alternatives. The authors of the volume's papers located this transformation in the 1940s, specifically in the wartime connections among economists, statisticians, psychologists, engineers, mathematicians, and

\footnotetext{
${ }^{1}$ I have refrained from using footnotes to ancillary arguments and indirectly related sources. The reader generally unfamiliar with the McCarthy years however will find an overwhelming array of materials to read and view as historians, psychologists, sociologists, political scientists, anthropologists, and literary and cultural critics have all contributed to our understanding of that period. For a quick introduction, perhaps useful for a historian of economics, the books by Schrecker $(1988,1998,2002)$ are required reading. Other useful works include Carleton (1985), McCormick (1989), Fones-Wolfe (1994), Selcraig (1982), Stewart (1950), and Maclver (1955). For a cinematic slice of that history, see De Antonio and Talbot (1964).
} 
physicists that produced the new disciplines of statistics ${ }^{2}$, operations research and management science. After the 1999 conference new historical work, much of it archive-based, examined the origins of this new mainstream economics with its new analytic techniques and methods. Scholars like Judy Klein, Philippe Fontaine, Philip Mirowski, Roger Backhouse, Robert Leonard, Till Düppe and Sonja Amadae went beyond the war's end in 1945 to examine economics in the Cold War years. Scholars from outside of the narrow History of Economics community — individuals like Ted Porter, Andy Pickering, Hunter Heyck, Paul Erickson, Mark Solovay, Joel Isaac, George Reisch, Daniel Rogers, and Lorraine Daston - further identified how disciplinary border crossings shaped the new economics. This transformation in historians' understanding of the development of twentieth century economics resembled historians' engagement with the continuity/discontinuity story of what some have called the Marginalist Revolution. World War II became the dividing line in the new periodization of "past" and "recent" economics (Backhouse and Fontaine, 2014).

The story of the mathematization of economics proceeded alongside narratives of the postwar stabilization of neoclassical economics (Weintraub 2002; Düppe and Weintraub 2014). Consequently arguments about how this changed use of mathematics in economics repudiated Marshall's views, or Veblen's, or Keynes', or Hayek's are of no historical relevance in the transformation story, no matter how important they may be in contextualizing the particular great man's writings pre-1940.

Below the surface of this new transformation narrative however is a sub narrative that appears to lend intellectual weight to that larger story. Specifically, it is sometimes argued that in the United States the transformation of economics from a political economy perspective to a scientific one was also associated with economists' desires to be safe, to seek the protective coloration of mathematics and statistics, during the McCarthy period. As McCarthyism was of course connected to the Cold War fears of communist infiltration and subversion of American institutions,

\footnotetext{
${ }^{2}$ Harold Hotelling created the first statistics department in a U.S. university at the University of North Carolina in 1946.
} 
particularly educational institutions, this McCarthyism argument seemed to fit easily within the economics-transformed-by-the Cold-War framework.

In what follows I will argue that this particular claim 1) is generally accepted, but 2 ) is unsupported by good evidence, and 3) what evidence there is suggests that the claim is false.

\section{Historiography of "McCarthyism and the Economics Community"}

The secondary literature on McCarthyism is immense ${ }^{3}$. Political scientists, historians, sociologists, philosophers, linguists, activists of the left and right, and popularisers have all written about this period. Most economists however know very little about McCarthyism and for historians of economics, what little they know comes from the explorations of a few individuals who have written about particular episodes of McCarthyite discrimination or harassment.

Two recent pieces by historians of economics concern the infamous harassment and purge of economists at the University of Illinois. The first paper on this subject, titled "Academic McCarthyism and Keynesian Economics: the Bowen Controversy at the University of Illinois" by Winton Solberg and Robert Tomilson, appeared in 1997 in the journal History of Political Economy. That episode, because it was so egregious and involved so many individuals who became quite prominent in the economics profession, including of course, Nobel laureates Franco Modigliani and Leonid Hurwicz, has long held economists' attention. Recently Antonella Rancan (2008), an Italian historian of economics, has re-examined this episode from the perspective of Modigliani.

A recent important paper (Giraud 2014) focused on the difficulties faced by MIT's Paul Samuelson in the creation and publication process of his Economics textbook. Although these questions arose in the immediate pre-1950 period, the McCarthyite involvement was associated with the attacks first on the principles textbook of Lorie Tarshis and then on Samuelson's book after they appeared (Backhouse 2013). That Samuelson wrote articles for The New Republic in that period

\footnotetext{
${ }^{3}$ I use "McCarthyism" in the narrow historical sense of the Oxford Dictionary: "A vociferous campaign against alleged communists in the US government and other institutions carried out under Senator Joseph McCarthy in the period 1950-4."
} 
also drew attention. The attacks on academic economists by Rose Wilder Lane and members of other right wing groups were brought to the fore by William Buckley's 1951 polemic God and Man at Yale. Again, while the attention to these kinds of issues by historians of economics has been slight, Americanists and political historians of the 1950s period have long discussed them.

A third set of interpretations and narratives concerning that period were developed and collated by the late heterodox economist and historian of economics Frederic Lee. As part of his $A$ History of Heterodox Economics (2009), Lee's chapter three, titled " Radical economics in post-war America, 1945-70", remains the best source on the post-war collapse of radical economics schools, communist and non-communist, and the persecution of radical individual scholars like Paul Baran. The Sweezy case at Harvard had occurred earlier but the McCarthy period was responsible for the disestablishment of labor union schools or worker schools with heterodox/radical/Marxist curricula. This period thus saw the demise of a truly radical economics subdisciplinary community in the United States. Those persecutions were real and damaged the lives and careers of a number of individuals who were not in fact mainstream economists or connected to such economists. This is well documented and had a permanent effect upon radical politics in the United States effectively divorcing the pre-war radical movement from the radical heterodox movements that were to emerge in the 1960s.

Aside from these general histories, there are sets of institution-specific case studies, usually part of broader institutional histories, to draw upon. As an example of this genre, the volume "Economics and the World Around It" edited by Saul Hymans was the set of papers delivered at the Centennial Symposium of the Department of Economics at the University of Michigan in 1980. Part two of that volume contains a paper by Margery C. Brazer titled "The Economics Department of The University of Michigan: A Centennial Retrospective." She explored, in the course of her narrative, the case of Lawrence Klein who was a subject of an investigation while on the faculty in the 1950 s and the difficulties he faced when caught between a couple of Neanderthal business professors in alliance with some members of the regents, and the Clardy subcommittee of the U.S. House Un- 
American Activities Committee investigating Communists in the state of Michigan. In Klein's testimony before that committee ${ }^{4}$, he renounced his past ties and named names of those whom he had met while briefly a member of the Communist party. The committee cleared him by denying that he was a subversive security threat. However the resistance to his being granted tenure by those right-wing faculty members, as well as a few regents, despite the enthusiastic support of the economics department's head and nearly all the department's faculty members, led him to leave for Oxford University. He did not return to the United States until 1957.

There is a third set of commentaries on the McCarthy period that a number of historians of economics might recognize, namely accounts - first person accounts - of the economist's experiences during that McCarthy period. One such memoir is found in Martin Bronfenbrenner's recollections of his time both as an economist with the occupation forces in postwar Japan (1988) and at the University of Wisconsin from 1947 to 1957 (1993). It was a source of pride to Bronfenbrenner that he had been scrutinized and investigated as a possible communist sympathizer during his years serving as an adviser in the American occupation of Japan ${ }^{5}$.

Another such account appeared in Modigliani's autobiography Adventures of an Economist $(2001,66-68)$ in which he recalled his experiences of the Illinois turmoil and remarked caustically on the McCarthyite attacks on both Bowen and foreigners (read Jews) who were automatically assumed to be communist sympathizers ${ }^{6}$.

${ }^{4}$ http://archive.org/stream/investigationofc195401unit/investigationofc195401unit djvu.txt (accessed August 25, 2015).

${ }^{5} \mathrm{His}$ father had left Russia on the run from the Czarist Okhrana since he had helped the sailors of the Black Sea Fleet "seize the city of Odessa". He and his family were also good "friends with, and perhaps relatives of, the Bronsteins, whose best-known product was Leon Trotsky" (Bronfenbrenner 1988, 3).

${ }^{6}$ Other autobiographical accounts along these lines, by individuals loosely connected to economics, include game theorist Anatol Rapoport's Certainties and Doubts (2000) and RAND applied mathematician (creator of dynamic programming) Richard Bellman's (1984) Eye of the Hurricane: An Autobiography. The recollections of Paul Sweezy, Walter Salant, John Kenneth Galbraith, Paul Samuelson, Evsey Domar, and Tibor Scitovsky, collected in Colander and Landreth's The Coming of Keynesianism to America (1996), all note on the effects of McCarthyism on economics in the 1950s. 
In her pioneering study comparing development of the economics professions in the United States, England, and France, Marion Fourcade cited Goodwin's discussion (see below) concerning the relationship of the McCarthy era to changes in the way economics was done. She wrote (88-89):

The Cold War had begun, and public and private patrons were nervous about the ideological implications of the research they supported. In 1952 and 1954 two successive congressional committees launched investigations into the activities of the major foundations on the suspicion they helped spread radical ideas. Similarly the social sciences were first excluded from the National Science Foundation at its creation in 1950 on the grounds that their messy politics might 'compromise the perceived ethical neutrality and taken for granted disengagement of natural scientists (Gieryn, 1999, 97)’.

Fourcade went on to provide brief accounts of a number of events affecting both economists and some economics departments in that McCarthy period. Besides noting the Stanford experience of Paul Baran, Paul Sweezy's at University of New Hampshire, the University of Illinois' problems concerning Dean Howard Bowen and his new economics department, she quotes Frederic Lee who suggested that "at least twenty-seven economists were explicitly harassed, or worse, during the McCarthy era" $(2004,180)$.

Without linking those McCarthy era events directly to the latter Cold War period, Fourcade noted that

[W]ith a scientific competition with the Soviet Union accelerating, dominant institutions in the research economy...increasingly embraced the formal methods' promise of efficiency, accuracy and mastery of the social and economic world. ...A review of funding patterns by the National 
Science Foundation over the 1958-79 period shows its heavy involvement in quantitative research and econometrics, notably in the areas of productivity and large scale modelling...[Moreover] the centrality of mathematics and economics is by no means unique to the United States, of course...[British] economists, as well as a large segment of the French economics profession, are also very comfortable with mathematics as a theory-building tool. " (90)

Fourcade leaves open the question of the retreat from political engagement by economists with the rise of technical economic analysis. She does not suggest that the former caused the latter. In other words, she makes no argument at all suggesting that the witch-hunts of the McCarthy period led economists to damp their political commitments and seek refuge in technical analysis.

Instead, Fourcade refers to Mary Furner (1975) who

has shown in her well-known study of these cases [academic freedom cases from the 1890's to the 1910s], the switch from 'advocacy' to 'objectivity' constitutes a key turning point in the history of American social science... In the case of economics... these pressures [i.e. political attacks against progressive social scientists] encouraged a retreat to a more narrowly 'scientific' discourse, which protected scholarship from easy vilification. Hence, not only did these cases help transform the social role of academics, who went from openly supporting social reform to a form of politically hands-off professionalism channelled through research bodies and expert commissions; they also had powerful intellectual consequences. In a context of political incertitude and relative lack of autonomy of the intellectual sphere, marginal analysis came to be regarded as a safe and attractive research strategy by American 
economists, especially by the younger generation who had to create a position for themselves (79-80)

For Fourcade then, the witch-hunts of the McCarthy period were similar in kind to the attacks on progressives around the turn of the twentieth century. The move to scientific objectivity was in part in response to those moves as the profession re-examined what it had to contribute to the larger conversation about economic well-being. Consequently, she draws no special inference about the transformation of economics into a mathematical - statistical discipline in the Cold War period.

At this point I must insist on emphasizing the distinction between "the Cold War" and "McCarthyism". The two are not synonymous. The Cold War itself need not have produced the excesses associated with the junior senator from Wisconsin. There were, to be sure, ideological attacks on "progressives" going back in the United States as far into the nineteenth century as one would wish. Attacks on those who though well of socialism, who supported labor unions, who wanted to talk about Marx, and so on would bring the wrath of the community, mostly the American business community, and the American Protestant church down upon them. Indeed after the Russian Revolution the U.S Attorney General A. Mitchell Palmer organized the deportation of "radicals" to the new Soviet Union. Radical ideas were alien and revolutionary and thus unAmerican. McCarthy was a demagogue in a well-established tradition of Henry Ford, Father Coughlin, and Charles Lindberg, exploiting Cold War fears and thus building upon on-going business and Wall Street attacks on New Deal policies. The Anti-Semitic and xenophobic nativists who had and have been playing such a role in American politics were not born out of Cold War fear of the Soviet Union. But McCarthyism itself did grow out of the Cold War hysteria. We can agree at this stage in the argument that the mathematization of economics was associated with the projects that developed during World War II, and that continued into the post-war Cold War era. It is silly to deny the influence of Cold War institutions like RAND in fostering the connections among operations 
researchers, game theorists, economists, political scientists, and defence planners. Many historians in recent years have been writing about these matters and have shown in important detail the Cold War connections among the post-war social sciences.

To claim however that this new mathematically inflected economics was a product of the Cold War period is not to say that it was a product of McCarthy's predations. Embracing mathematics to escape McCarthyite scrutiny is a claim different from a claim about the Cold War's important role in the transformation of the social sciences.

\section{The Standard View}

Before we go into more detail about possible evidence supporting the "McCarthyism produced mathematization" argument, let us examine several contexts in which the claim has been made. We will then better understand the claim's curious role in historians' construction of their now standard narrative of the triumph of neoclassical economics in the Cold War and post Cold War period.

Craufurd Goodwin's paper "The Patrons of Economics in the Time of Transformation" appeared in the volume by Morgan and Rutherford. Continuing his long-term interest in how economics evolved in connection with non-academic players - quasi-government policy groups, government institutions, and eleemosynary institutions - Goodwin focused precisely on the role of institutions like the Ford Foundation in shaping the new economics. Because his discussion has become canonical for historians of economics, I need to quote from it at length:

Leaders of higher education during these years can perhaps be pardoned for having hesitated to appoint or promote an economist likely to bring down on the institution the wrath of several vital external constituencies: members of the governing body, legislators, donors, or alumni. So how are the administrators likely to respond? Eliminating the subject from the curriculum was not an option; the economy was too central to the 
American ethos for that, and student demand was too strong. Even

[William] Buckley conceded that about one-third of the entering class at Yale in 1946 had enrolled for Introductory Economics. The only administrative option was to appoint economists of a different kind. But what kind? What behavioural characteristics were to be avoided? Why did certain economists so enrage the patron community? The reason was, in part, Buckley said, that so many of the offending economists seemed to reflect a collectivist ideology at variance with the individualist mainstream of America. ...It was particularly offensive that these dissenting economists chose to express their views not just to scientific colleagues in codes that only the initiated could comprehend but also to external audiences that ran the gamut from the local Rotary Club to the U.S. Congress. It was mainly because Ayers contributed to the New Republic, Galbraith wrote best selling books (and became head of the American Civil Liberties Union), and Tugwell figured prominently in the New Deal that their ideas became so troublesome to the patrons of higher education. ...Yet there was another kind of economist who did speak in tongues mainly in the cloister. This neoclassical economist had all the virtues many of his "plural" brethren lacked. Therefore, when hard-pressed administrators were faced with a choice between these two types of economists, can we doubt where their better judgment would have lead? ...Assessing the effects of administrative repression on the professional behavior of scholars, Lazarsfeld and Thielens $(1958,257)$ found that [a teacher who had himself been the target of an incident was especially likely to be apprehensive.] But how about the others? The result was not very different. Lazarsfeld and Thielens produced an 'index of apprehension' that shows a clear 
increase in apprehension with 'increasing numbers of corroborated incidents reported', even among those not directly affected (259).... Lazarsfeld and Thielens did not ask the next obvious question: how might professors be expected to change their own behavior to relieve their apprehension? ${ }^{7}$ My speculation is that they would have foresworn interwar pluralism for postwar neoclassicism (Goodwin 1999, 60-62).

Goodwin was a Vice President of the Ford Foundation in the 1960s and early 1970s, so his understanding of how such institutions "work" is both first-hand and as a scholar of the period. Moreover, both as a Professor of Economics and Secretary of Duke University around that time, he saw how academic institutions, through their boards of trustees, eschewed controversial faculty appointments. His perspective provided more than usual weight to the idea that the mainstream of the economics profession moved to a politically quieter technical enterprise in the 1950 s.

Mary Morgan (2003) endorsed his interpretation in Porter's and Ross's Cambridge History of the Social Sciences volume. She wrote (296):

The thesis that American war and Cold War experience were critical for the turn of American economics to a tool-based discipline in general, and to neoclassical economics in particular, requires amplification. Tool-based economics had been important in the American experience of fighting the war, not only in economic policy terms but in other areas as well, for mathematical and statistical techniques and modelling could be turned to many ends, specifically to direct war aims. ...While war work supported tool-based economics, the American political movement against communism in the later 1940s and the McCarthyism of the early 1950s decided the issue in favour of neoclassical economics at the local level.

\footnotetext{
${ }^{7}$ In fact, Lazarsfeld and Thielens asked exactly those questions. We will attend to this point below.
} 
Although the overall picture has yet to be filled in, it is clear that economists had to be careful in expressing their views.

At this point Morgan had a footnote to Ellen Schrecker's No Ivory Tower (1986) and Goodwin's (1999) article. Morgan went on to say that

One economist [i.e. Goodwin] writing about this period suggested that moving to tool-based economics was a defensive option against ideological persecution, though this sometimes proved to be an inadequate defense, particularly for those whose values were not aligned with the new ideology. There are examples of American economists of mild left-wing sympathies (including one future Nobel Prize Winner, Klein) leaving the United States for the safety of Europe ${ }^{8}$. Others who held such views remained, for the effects of the loyalty oaths and McCarthyism were uneven. (296-297)

She argued that McCarthyism - in some measure to be determined only when "the overall picture is ... filled in" - was to some extent responsible for the move of the economics mainstream toward a more tool-based (mathematical and statistical) mode of conducting and expressing research. She thus suggested that the mathematization of economics in the post-war period was related to economists' desire to hide their political sympathies at a time when expression of left-ofcenter political views was professionally dangerous.

Goodwin and Morgan are both eminent historians of economics - both are Distinguished Fellows of the History of Economics Society — and their shared understanding that McCarthyism fostered the mathematization of economics has shaped the conventional view. What however is

\footnotetext{
${ }^{8}$ Klein as a communist party member had been more than "mildly left-wing". See footnote
} 3. 
curious is the lack of evidence brought forward to support the claim. Consider how this line of argument developed. Morgan cites the earlier piece by Goodwin. Goodwin cites the earlier book by Lazarsfeld and Thielens. That original piece provided however only indirect evidence of something, namely a correlation between the respondents' reports of known incidents, and the respondents' degree of "apprehension". Goodwin provided no substantive discussion of that Lazarsfeld and Thielens report. In fact, in my extensive search of the economics and history of economics literature, Goodwin's citation of their report is the single such citation by any historian of economics of any type. Thus there is scant evidence on offer for the claim that McCarthyism, even with the fears and concomitant sensitivities of university administrators who faced potentially hostile legislators, members of their trustees, visiting committees, and the local and national business community, was responsible in some part for turning the economics profession into a de-politicized tool-based community.

Before further examining the "McCarthyism produced mathematization" story, we need to attend to another important context in which the claim has been made. We will then better understand the claim's curious role in historians' construction of their now "standard" narrative of the triumph of neoclassical economics in the Cold War and post Cold War period.

\section{Critics of the New Mainstream Economics}

The historical muddle that is associated with accounts of the development of economics in association with McCarthyism, the historiographical problems alluded to earlier, arise quite clearly in the work of several critics of mainstream economics. We must again caution the reader that "the Cold War" and "McCarthyism" were not the same historical episode. They cannot be, as causes of anything, be the same.

Philip Mirowski, the most vocal of the historian critics of mainstream economics, launched his protest against mathematical economics and economic theory not from the point of view of its obscurantism, or its inattention to real world problems, but because of its connection to a Cold War 
perspective. His vision of mainstream economics as it developed in the postwar period is one of the capture of economics by individuals and institutions indirectly connected to John von Neumann, the person who facilitated economists' engagement with Cold War theorizing (Mirowski, 2002). The fact that detailed analysis and solution of optimization problems appeared to be lodged at Cowles and that von Neumann had met Koopmans (and Marschak) during their Princeton years led Mirowski to present a capture theory of Cowles economics. In contrast to the older stories of Cowles development in Colorado Springs, its focus on econometrics in those years, and its uneasy coexistence with the University of Chicago economists, Mirowski suggested that the more important Cowles story was that it was a hotbed of socialist planning devotees, who in the McCarthy period rushed to join von Neumann, RAND, and others in proclaiming their fealty to American ideals while masking their political loyalties under a veil of mathematical theory.

Whatever the wider doubts about the intellectual coherence of 'Marschak's market socialism,' the American military was one place where unquestioned adherence to the virtues of the market cohabited cheerfully/truthfully with the most vaunting ambitions of centralized command and control, without ever provoking any hand-wringing about conceptual consistency or soul-searching over freedom. Indeed, for researchers of a certain political stripe, the security clearance required for military consultants could be worn proudly as a badge of legitimation, serving to ward off a modicum of superficial distrust or the ubiquitous pall of McCarthyite suspicion (Mirowski 1999, 256).

Mirowski situated Cowles in a particular place, Illinois, at a time when anti-Communists were investigating not only the University of Chicago but also the University of Illinois (Selcraig 1982). Going into the political backgrounds of the Cowlesmen, Mirowski stressed their potential vulnerability in the McCarthy period. His logic entailed that Cowlesmen were unprincipled 
opportunists, hiding their political sympathies in order to pursue their deeper theoretical interest in mechanisms of planning. This argument is difficult to sustain. Would it not be equally likely that many of those who took up work for the military were anti-Socialists and anti-Communists? With the vision of "planners need to plan" and "the military needs planners", the marriage between Cowles people like Marschak and Koopmans and the interests of RAND in supporting military research was, for Mirowski, made in Cold War heaven.

Sonja Amadae developed a similar critique of postwar economics in her 2003 book Rationalizing Capitalist Democracy: the Cold War Origins of Rational Choice Liberalism. For example, in her discussion of the Ford Foundation's role in developing social science research in the 1950s she pointed out that McCarthy's investigations of the foundation were initiated in a letter from McCarthy to the foundation dated March 19, 1953. This led to "the Ford Foundation's swing to the right [that] coincided with the anti-Communist sentiment then sweeping the nation and led by Senator Joseph McCarthy". Her argument is quite focused and so I quote from it at length: (158 et seq.)

The mathematical formalism structuring rational choice theories is impelled by the same academy-wide momentum propelling an increased emphasis on formal models as an indication of scientific standing. This movement has sustained attention by historians providing accounts of disciplinary transformation in the American social sciences, especially following World War II. [At this point, she provides a footnote to a book edited by Klausner and Lidz (1986), which was primarily concerned with the issue of Talcott Parson's role in the SSRN's attempts to improve social science's status in the discussions and legislation surrounding the creation of the NSF.]

The priority given to mathematically articulated research findings has two rationales. First, in the wake of WWII, during which scientific analysis 
of strategic problems proved useful to the war effort, additional

mathematically oriented research was supported as a response to the Soviet Union's successful launch of the Sputnik satellites. Money was thus channelled to research endeavours that provide a quantitative analysis of social issues. Second, this preference for mathematical formulas and models served the function, as RAND leaders realized, of depoliticizing research by translating contentious social debates into the 'objective' language of mathematics.

There is no evidence provided concerning "RAND leaders and their realization". This theorized assertion is curiously ahistorical as well when one realizes that Sputnik was launched in 1957: surely this was not part of the McCarthy period.

She went on (159) to quote Thomas Bender's finding that "by 1950 the intolerance generated by McCarthyism and the Cold War moved academics and intellectuals generally to make themselves and their work less vulnerable to attack" (Bender 1997, 13). Bender's observation, while acknowledging the impact that Cold War fervour had on American academics, was part of her own master narrative situating the formulation of rational choice theory as a direct response to the intellectual puzzles bequeathed to the Cold War generation by Marxists. Amadae wrote "Bender claims that the 'political scientist David Easton has found in McCarthyism a stimulus for development to a more scientific and objective political science', for it provided a 'protected posture for the scholar.'" Her footnote 10, at this point, does not provide a source for Easton's statement. One needs to go to Bender's article to locate it (Easton 1991).

Note that Amadae used Bender to present the views of David Easton. Easton himself was interested in the transformation of political science in the United States. He in fact wrote $(1991,43-$ 44) about the social forces that encouraged a commitment to the introduction of science into the study of politics. 
Early in the Cold War period in relations between the United States and

the Soviet Union...Senator Joseph McCarthy inaugurated and led a reign of

psychological and legal terror against liberals and others in the United

States. Scholars were selected as particularly vulnerable targets for attack.

McCarthyism succeeded in driving underground an interest in social

reform and critical theory.

From this perspective, objective, neutral, or value-free research

represented a protective posture for scholars, offering them intellectually

legitimate and useful grounds for fleeing from the dangers of open political

controversy. ...McCarthyism, of course, had nothing to do with the

emergence of behavioralism as a new approach to political research.

Easton's argument, presented without any evidence besides his common sense, was that the price of doing social reform and critical theory had increased, and therefore scholars demanded less of it. But it is crucial to recognize how Easton's argument slides from "the Cold War" to McCarthyism" as a causal mechanism for the change in political science research ${ }^{9}$.

${ }^{9}$ It is worth noting that similar arguments have been made abut the discipline of academic philosophy in the United States. Philosopher John McCumber (2001), in his book Time in the Ditch: American Philosophy and the McCarthy Era, argued that the move from varied brands of philosophy done in academic settings in America prior to the McCarthy period gave way entirely to a style of analytic philosophy that left aside political and moral commitments. Philosophy of science and mathematics, and symbolic logic replaced political philosophy and forms of pragmatism as central concerns of American philosophers. In a more refined study, George A. Reisch's book How the Cold War Transformed the Philosophy of Science (2005) showed in rich detail how the Unity of Science movement of Otto Neurath and Philipp Frank was vulnerable to McCarthyite attacks in the early 1950s. The prewar leftwing sympathies of many philosophers opposed to Hitler's totalitarianism supported their optimism that scientific planning, as they believed (we now know falsely) organized the Soviet Union's economy, was the best hope for a humane future. As Reisch shows, such views of science, and the philosophers who promulgated those views, were mostly silenced by McCarthyism. The subject matter of the philosophy of science was thus circumscribed to the fields of logic, metamatematics, and related formal studies in epistemology. The structure of science and scientific explanation, not science's larger use and impact, were to be its new subject matter. 
One of the most egregious examples of bemoaning the postwar mathematization of economics is found in the paper by Paul P. Streeten (2000) in the Pakistan Development Review, though the paper has been multiply reprinted. He wrote (204): "One may be forgiven if one feels some forms of mathematical economics should be an activity permitted only between consenting adults in private, or that it resembles masturbation in that it yields enjoyment to the practitioner without having to make any contact with outside reality. "

He went on to ask

What are the reasons for this dominance of mathematics, for the priority of form over content, of technique over relevance and realism? ... Among other internal reasons is the already mentioned beauty and elegance of mathematics, the prestige attached to it, and the standards of excellence evolved from within mathematics. But I suggest among the external reasons there may be one unto which little attention has been paid. The political pressures of McCarthyism in the 1950 s played, I think, an important part. Economics deals with people's pockets and their ideals: a highly explosive mixture. To be accused of criticizing the capitalist system and pandering to socialism was very dangerous in the 50s. Yet, any honest economist looking at the real world would have had to come up with some criticisms. So mathematics provided a safe escape mechanism that drove economists away from political and economic reality.

This argument too is unsupported by any evidence. Streeten simply assumes that all right minded individuals who happen to be economists will instinctively wish to criticize the capitalist system. And, from a position of criticizing the capitalist system, in the 1950s at least one would have been identified with those Cold War enemies. The McCarthy period thus pushed economists, all 
"honest" right thinking economists anyway, into mathematical economics in order to hide their views or protect themselves from being seen as enemies of America. Streeten does not recognize that many right thinking economists might have been proud to stand up and proclaim in front of Congressional committees that the economic system of the Soviet Union was economically inefficient, and thus a slow-moving disaster. Keynes, and Calvin Bryce Hoover, following visits to the Soviet Union around 1930, had argued that the Soviet command economy was not only inefficient, but necessarily cruel with respect to civil liberties and personal freedoms. Most right-thinking economists believed them both then and later.

There is a second issue that sits uneasily alongside Streeten's primary argument. It is well to comment on it here for we will have to come back to it later. Streeten suggests that those who began to employ mathematical forms of argument in the late 1940s and 1950s were moral cowards. They did not in fact stand and fight the good fight against capitalism but rather capitulated to the forces of oppression and fascism represented by American McCarthyism. Yet on this argument, it is hard to see why outside the United States there should have been much interest in the mathematicization of economics. Econometrics in Norway and the Netherlands and England becomes inexplicable. There was no McCarthyite push there. It confounds Streeten's argument. Nor can it usefully address the obvious question of why, after McCarthyism died, economists still failed to fight that good fight against capitalism. Streeten is presenting a moral claim: it is good and right to criticize capitalism. But since criticizing capitalism was in his view inconsistent with, or probably incoherent in, a mathematical argument, those who used mathematical and formal arguments were shunning an ethical duty. We should not therefore respect them or the work that they did. This may seem extreme but it is fully consistent with the coherence of the antimathematical vision of what used to be called the "Post Autistic Economics" community, now the "Real World Economics" community, a heterodoxy with its own journal that bestows moral superiority on anti-neoclassical economics. We will return to this point. 
A much more sophisticated discussion appears in Philo A. Hutcheson's "McCarthyism and the Professoriate: A Historiographic Nightmare?" that appeared in 1997. He began by noting that

[T]wo key historical questions arise. The first, given the repeated attacks on professors and the conduct of higher education at the time is the historicity: 'what happened?' ...The second question is fundamental to the nature of historical inquiry: 'Can we know what happened?'

He presented a lengthy discussion of the nature of McCarthyism and, unlike Streeten's, Hutcheson's discussion was fully documented. He went through many of the notable cases in which McCarthyism produced difficulties for various colleges and universities as well as individual professors. His conclusion differed somewhat from a number of other authors.

[E]ven in de facto terms, the boundaries of autonomy for the professoriate are weak. The professoriate does not enjoy economic or social defences. Neither unions nor big business protect professors, and churches have contested professors and their ideas since the Board of Overseers dismissed the second master of Harvard College because of his opposition to infant baptism. In essence, society grants the professoriate its autonomy and thus may choose to take away that condition. The historical political conditions of autonomy are extraordinarily problematic. In this regard, accusations of timidity or equivocation tend to lose their accuracy; courage without power is unlikely to endure, resulting more often than not in martyrdom or sainthood - conditions often found in the works on McCarthyism and the professoriate. The academic profession apparently demands principled response as the method for the collectivity to use in the event of attacks on the occupation. It is not clear, however, that 
reasoned defence would suffice... the results which Lazarsfeld and Thielens report, that professors did not feel especially denigrated by McCarthyism [N.B. see below], confirm the latter evaluations of McCarthyism as more rather than less characteristic of United States society. ... Higher education was able to continue business as usual. ... [P]rofessors have long been willing to compromise standards of truth for the service of the state. Those professors who attack colleagues, those professors who fail to support colleagues, were inheritors of a long tradition...

In conclusion, what may be most troubling for the professor qua professor examining the issue of McCarthyism and the professoriate is the actual nature of the professoriate. While most scholars writing on the issue of McCarthyism and the professoriate acknowledge the tenuous nature of academic freedom, it is far less common in the literature to find expressions of concern about the acute vulnerability of the professoriate. ...For an accurate historical point of view, the scholar must acknowledge that academic freedom has always been tenuous; such events as McCarthyism point to the ambiguous and tenuous nature of academic freedom, not that it is such only in times of crisis (620).

Economists' fears of McCarthy-ite attacks were real. Many economists saw other scholars' careers destroyed and many educational institutions damaged. Universities were unprepared and/or unwilling to defend the academic freedom of their professional staff. The question remains, though, what was the economics profession's response to these paralyzing attacks ${ }^{10}$ ? We have not yet seen

\footnotetext{
${ }^{10}$ The Committee on Academic Freedom and Civil Liberties of the American Economic Association was virtually impotent in the McCarthy period. Its reports, in the various volumes of the American Economic Review's Papers and Proceedings (e.g for May 1958-60) are mostly reviews of cases brought elsewhere, like Paul Sweezy's trials at the University of New Hampshire, and the U.S. Supreme Court's finding in Sweezy's favour.
} 
evidence that scholars redirected the modes of inquiry that they had employed. We have not seen how McCarthyism and mathematization were in fact connected. We do though have a privileged window through which we can study these issues.

\section{The Academic Mind}

During the spring of 1955 Columbia sociologist Paul F. Lazarsfeld and his research team conducted a set of interviews in order to answer questions that had been initially posed by Robert M. Hutchins of the Fund for the Republic. Hutchins, and others who were being harassed during the McCarthy period, was concerned about the pressure that was being put on universities and their faculties.

[To] understand the outcome [of the McCarthy period's attacks on higher education] eventually, the positions generally taken by college teachers at the time will have to be known. What actually happens is always the resultant of both the forces which impinge upon people and the way they look at and feel about them. If in addition one wants to affect the course of events, an understanding of attitudes may be even more important. (vi)

The commissioned study was based on interviews with university teachers. Because of the authors' belief that university faculty members in the social sciences were most likely to have been affected because of their professional engagement with the kinds of social issues that concerned McCarthy and others, they created a sample of such faculty. The sample size was 2,451 social scientists at 165 colleges and universities. The interesting part of that study for our purposes is that the total sample included 565 economists, $23 \%$ of the total group interviewed. The sample was generated randomly and the individuals were selected randomly. For this reason it is useful to think 
of the overall results as pertaining to the economists. However, and this is the key point, the original questionnaires and their answers, the actual records, are preserved among the Paul Lazarsfeld papers at Columbia University's Butler Library. Examination of a sample of those questionnaires showed that although there were no identifiers of schools or individuals in the published work, the actual questionnaires contained exactly that information. In what follows I will describe the exact information available in a sampling from four boxes of questionnaires. Thirty-one economists do not a generalization make, but will give us some sense of the effect of the McCarthyism of the period on economists.

Some of the questions were designed to elicit views of social scientists on attitudes held about them by others. For example, "professors, at least social scientists, seem to consider themselves an occupational minority towards which significant sectors of the community hold relatively contemptuous attitudes." (14) Moreover, "Broadly speaking, from either the long- or short-range point of view, American social scientists felt in the Spring of 1955 that the intellectual and political freedom of the teaching community had been noticeably curtailed, or at least disturbingly threatened." (37)

It is not necessary to go into much detail concerning the kinds of accusations that were made against faculty members. Being labelled a Communist was not unusual in that period: "Such cases suggest that in this period an individual can be called a Communist for almost any kind of behaviour, or for holding almost any kind of attitude. ...In one case a faculty member was accused of being a Communist. The president of the school stated 'after all, he has been interested in interracial relations, which the communists are interested in.' He was dismissed." (56-57)

The intellectual core of the study was set out in Chapter 3 of the book. From the preliminary interviews Lazarsfeld had supervised, he and his team created

a list of about 20 relatively specific experiences. Questions were then worded so that the respondent would simply have to say whether or not 
these things had happened to him ${ }^{11}$. It was necessary to present a large number of situations related to academic life which might cause a teacher concern or induce him to act contrary to his convictions; depending on personality and background factors, one man's apprehensions might express itself in regard to his publications, while for another relations with students or with neighbors might be more indicative. (73)

The chapter's title was "A Measure of Apprehension", and the results suggested that eleven of the items could be used to create an index of apprehension. These were further divided into two categories "One pertaining to feelings of worry about security, the other pertaining to precautionary behaviour." (74)

Given our own concerns here, it is the second of these that will concern us. The results of the questionnaires are compelling: "We thus arrive at a rather far-reaching conclusion. There is indeed widespread apprehension among these social science teachers, but in generally it is hardly of a paralyzing nature; the heads of these men and women are 'bloody but unbowed'." (95)

In other words these individuals were probably worried but appear to have taken few if any actions as a result of that worry. And there is no evidence brought forward to suggest that the kind of work they did was affected by those worries.

Taken together with those given earlier, these figures [based on the questionnaires] can indicate that the majority of teachers felt no curtailment of their own academic freedom or that of colleagues. But they also suggest consistently that a noticeable segment of our respondents and their colleagues felt intimidated by the difficult years - by fear of attack and harm to their careers that might result from a free expression of their views. (196)

${ }^{11}$ There were virtually no women in the sample of economists. 
A small minority of respondents scored high marks on the apprehension scale. Nevertheless, the constraints on their professional work appear to be minimal. Various respondents said that they did tone down writings on controversial issues, and one economist said he "had developed a simple formula for avoiding trouble: 'I just slant my writings to things that Congressman can't understand'." (218-219) But that did not translate to larger sets of modifications of professional behaviour. There's no evidence in any of the questionnaires that any respondent changed the nature of his research. While there is some evidence of some toning down of classroom material that might be offensive and draw charges of sympathy to communism, as professionals there seem to be no change in what they did.

The response to The Academic Mind was respectful and serious. It was reviewed in a very large number of journals and appears to have been discussed and evaluated at many sites. It is incontrovertible that the book mattered and helped shape what became a standard view over time, namely that university faculty had indeed felt intimidated and distressed during the McCarthy period, worried about their own security and status. This book then helped form the overarching narrative of the threatened nature of academic freedom during the McCarthy period and the way in which free inquiry was threatened by the paranoia of rabid anti-Communism. The book's specific conclusion that there was no significant evidence that academics changed the nature or direction of their academic work seems to have gotten lost.

There were only a few doubters or sceptics with respect to the book. Lionel Trilling writing in The Griffin in 1958 suggested "the professor lives characteristically by his acute awareness of the particular pathos of his situation. It is one of the fringe-benefits of his underpaid profession that he can suppose that he is among the insulted and injured, a marginal man, and therefore, according to the modern calculus of morality, a morally justified man" (4). Trilling went on to suggest that the status of the professoriate has changed in the postwar period and that the older view of the academic as lowly paid and of low status no longer characterized academic life. He regarded the reaction of the academic community as somewhat overdrawn though he agreed that the numerous 
episodes of harassment and firings were quite real. He remained unconvinced however that the spirit of the academic profession was crushed in that period.

Reinforcing Trilling's belief, in a remarkable retrospective look at the volume, constructed for a law symposium on academic freedom, the book's co-editor Wagner Thielens stated that "First, in key ways, the academic profession was vulnerable all along to attack from the right. Second, during the late 1940s and early to mid-1950s, the attack came, and caused considerable damage. Third, many signs in our data indicate that the damage was less than liberal authors like Mr. Hutchins thought certain" (Thielens 1996, 2).

Thielens went on to observe that academic social scientists were indeed more "left of center" than the American citizenry at large, and were thus, in their tolerance for non-traditional political ideas, more willing to accept a communist's beliefs as private and unassailable: "I believe that by taking such a stance, in an era when disagreement and disapproval could quickly turn into open charges, social scientists made themselves vulnerable "(op. cit., 3). The substance of the article supports Thielens' central point: the attacks were real, did some damage, but for the most part were resisted both on personal and institutional levels. It is in the "for the most part" that disagreements may arise. He mused "All together, in the two professional matters [of sanitized teaching and research], at least one conclusion seems fair: The situation was bad, but could have been much worse" (op. cit., 6). The remainder of his paper attempted to explain, using the survey data, "why the academic persona ... worked in several ways to limit the success of the McCarthyite attacks" (op. cit., 7).

No Ivory Tower (Schrecker 1986) had offered a different perspective. Framing matters in terms of the history of the responses of the academic community to the external threats represented by pressure from the business community, congressional committees, often by their own academic administrators, Schrecker went into sufficient detail to convince most all readers that something had indeed happened, and it was not pretty. Her case was convincing and appropriately intertwined with a history of progressive thought up through the McCarthy period. Academic 
freedom was never as secure as academics wished it to be, and the attacks on the academic community had gone on almost since the beginning of the academic community in the United States. Academic freedom was always under fire. Indeed what constituted academic freedom was very much at issue. The weak response to, or at worst collaboration with, the McCarthyite forces was not from the scholars, but the colleges and universities themselves. Too infrequently did the institutions of higher education protect or defend their faculty from outside attacks.

But what of the economists? Where does the economics profession fit in the larger narrative of the attacks on the academic community during the McCarthy period? Were economists more or less likely to be singled out for attack? In the next section, we'll examine some of the specific questionnaires themselves, and some representative economists' view of their attitudes and behaviors during that period.

\section{Economists Speaking}

In Fall 2014 Mr. Harun Buljina, a PhD student in history at Columbia University, examined under my direction four boxes (Boxes 9-12) out of ninety boxes of completed questionnaires archived in the Paul F. Lazarsfeld Papers at Columbia's Butler library. The four boxes contained completed questionnaires of thirty-one economists identified by institution and name. Each questionnaire had twenty-eight pages of structured questions and the economists' hand written answers. The interviewee could also elaborate on any answer on the blank facing page, which also contained the interviewer's notes of explanation on follow-up statements made by the interviewee. My short synopses of the relevant responses appear in the Appendix. There numbers preceding the names refer to the questionnaire number. Note that question \#26 specifically asked the interviewee whether the then current political climate had affected his [there was only two woman in my subsample] research activity at all.

In this selection of thirty-one economists there are expressions of concern about the general climate and the related belief that academic freedom is being somewhat harmed, but in no case was 
there any hint of change in research agenda, research techniques, research orientation, use of materials in research, and so on. People were doing whatever they had been doing and they continued to do it. Moreover, question \#26 directly asked whether they knew of others who had had their research affected and no one knew anybody in that category. There is some level of apprehension but in terms of their job security and career prospects, it was extremely low. It's difficult to see where any conclusion could be drawn about economists changing the way they did economics to make it more technical or tool-based and thus unassailable by bigoted legislators, headline seeking congressional committees, union hating businessmen, conservative trustees and so on.

Surely though with the claims about how economics changed in the face of McCarthyism we would have expected to see some trace of an "escape to mathematization" in our excavation of the ruins. The evidence however fails to confirm any such thing. What then does that evidence tell us? First, it tells us that historians' use of the phrase "economics community" during the McCarthy period is too biased in favour of a numerically small professional elite to be applicable to the larger actual American economics community during the McCarthy period. Historians of economics, mostly economists, Whiggishly focus on heroic narratives of progress and so the relevant community for them, unconsciously perhaps, consists of economists who are thought to contribute to that progress. If one doesn't publish, one won't win a Nobel Memorial Prize. But of our thirty-one economists, only three can be said to have become well-recognized producers of new economic knowledge, namely Becker, Williamson, and Steiner all of whom taught in (now) elite Research 1 universities. Most of the others were primarily teachers of economics, and were far from the towers of Harvard, Yale, and Chicago and the offices of RAND, Cowles, and the Ford Foundation. Not all of the economists surveyed had PhDs, and many taught business type courses even though they were not in business schools. Most were either in public universities and colleges with service missions or in religious private schools, and appear to have lived non-controversial lives. Aware of McCarthyite attacks, they themselves were not much concerned. And their responses to Question \#26 denied 
that they changed any scholarly behaviors. Put another way, generalizations about how economists reacted to McCarthyism appear based on an unusually constricted view of who were those "economists" whose reactions "matter".

Second, there is a stock-flow problem that is not addressed in discussions like those of Mirowski or Streeten. Put crudely, it is hard to teach old economic dogs new mathematical tricks. The number of academic economists dwarfs the number of new economists coming into the profession each year. There were around 125 economics (non-business, non agricultural economics) Ph.ds granted in 1947, rising to around 131 in 1954, and only a portion of them would seek academic jobs. After the end of the worst of the Red Scare period, in the late 1950s with creation of the National Defence Education Act (NDEA) and NSF Training grants, graduate economics programs were able to increase the size of their graduate classes. So the average level of mathematical training possessed by economics department faculty members increased only slowly as new hires were for the most part matched with retirements. The entry of enough mathematical/econometric hot shots to effect the profession's change would take another decade at least.

Third, the conventional narrative about a profession's retreat into analytic rigor seems to suggest that most economists were hidden socialists who, out of political self-interest, learned how to solve, and love solving, dynamic programming problems. However surveys of faculty political commitments continuously showed, and show today, that business school faculty, engineering faculty and economists are more conservative than science and humanities faculty members. The preserved questionnaires indeed show a lot of votes for Eisenhower over Stevenson. Why, if "I liked Ike", or I liked the non-mathematical Veblen, would I struggle to master the Hahn-Banach Theorem?

\section{Conclusion}

Former Secretary of Defence Donald Rumsfeld sanctimoniously opined about Saddam Hussein's weapons of mass destruction that "Absence of evidence is not evidence of absence." Social scientists today are quite aware that journal editors do not welcome submissions in which the 
author attempts to establish a result and fails to do so. Unlike the natural sciences where a failure to confirm or to replicate is regarded as an interesting event, such is not the case in the social sciences. Thus too in the history of economics.

I've attempted to assess the claim that a major contributing element to the mathematization of economics in the post-war period was economists' defensive response to the era's McCarthyism. Safety it is said was to be found in formalization and quantification. This argument has been made on a number of occasions and seems to serve several different purposes. In tracking down the evidence for this claim though, we found a circular set of references apparently based on a misunderstanding of the primary data source, the book The Academic Mind.

Pulling back the non-evidentiary curtain further we've learned that the reasons for making such a claim appear to vary from writer to writer. For several of the scholars writing on the subject, their larger point is the interweaving of two particular stories in the history of economics: First, there is the increased mathematization of economics going into and then throughout the post-war period and second, there is economists' responses to McCarthyism of the Cold War years. Scholars engaged with the second of these topics appear further to divide into two groups. The first is concerned with the destruction of radical and heterodox economics traditions as a result of the very real persecution of radical economists in the late 1940s through the 1950s. Frederic Lee has written most powerfully about these events and concluded that economists who were both radical and in the public eye were systematically removed from colleges and universities. Even more destructive of the labor-based radical community was that the radical, socialist, Marxist, and labor union schools which were long a part of the American urban scene were nearly all shut down.

The second group of scholars examining this McCarthy cold-war period have told a story of the "capture" of the mainstream of the American economics community by Cold War imperatives organized around research undertaken at RAND and through the various funding agencies of the military like the Office of Naval Research. Such scholars have as their larger project destabilizing the mainstream economists' vision of a coherent and heroic past in which economic analysis moved 
from darkness to light, arguing instead that a robust and healthy community was corrupted by military imperatives and easy money.

Those concerned with telling a complex and multi-layered story of the transformation of economics in the post-war period are generally more willing to provide nuanced accounts of both internal and external moves on the part of the economics community as it adjusted to, and sought accommodation with, the new world of larger universities, reasonable availability of public research funds, and an increased demand for the services of technically trained economists.

There is of course, behind all these stories, the larger effort of American political and intellectual historians to examine the post-war cold-war period of McCarthyism. They have provided a rich contextualization of these events in the history of American higher education and the history of abridgements and defences of academic freedom. Some of these histories were meant to expose the roots of particular attacks on scholars and their institutions while other historians have examined the backstories that eventuated in the turmoil. The definitive examination of universities and McCarthyism by Ellen Schrecker was sensitive to these complexities in a way that historians of economics have not been.

Any economist or historian of economics familiar with the history of the American economics profession is well aware of the tensions and conflicts surrounding nineteenth century economists who spoke openly on matters like free trade, bimetallism, monopolies, immigration, and unionization. The role of government in correcting or counter balancing the worst tendencies of crony capitalism and its related vice of rent seeking is well known. It was not easy in the 1890s in Wisconsin for an economist publicly to defend labor unions against the political establishment. Nor is it easy in 2015 in Wisconsin to do so either. In days past one might attempt, if one were a regent or legislator, to fire the economist. Today the trustees or their legislative and executive bosses simply subpoena the scholar's emails [as in Michigan and Virginia] or shut down the scholar's Poverty or Labor Relations Center [as in North Carolina]. Now, as then, calls for a larger public service role for government, and greater attention to economic injustice, can lead to the public 
accusation that those economists are socialists attempting to subvert American values. Then, as now, a concern for addressing issues of inequality of wealth, of income, of education, can lead to the grave accusation of anti-Americanism. Obama is, or is he not, a socialist?

We have some sympathy for the argument that, in the post-war period, scholars in colleges and universities were becoming more not less important facilitators of achieving was termed "The American Dream". They taught the children of those Americans whose aspirations were that their children's' life experiences and economic successes would exceed their own. Economists played an important role in that period, providing a technical expertise to managers of the economy, and managers of American business. In contrast heterodox economists and social critics recirculated old arguments about the soullessness of economics and economists. That line of heterodox criticism of mainstream economics invariably located the sources of such coldness in the profession's failure to deal with real problems. What could buttress their claim that economists' models don't correspond to "reality"? One of the uninformed answers given cited the moral cowardice of economists who, like victims of the Stockholm Syndrome, acquiesced in their own intellectual demise during the McCarthy period. It provided an easy explanation. That the explanation appears, upon examination, to be non-evidence based has gone unremarked.

The postwar rhetorical shift in economics had deep roots and wide appeal. In an earlier study (Weintraub 2002), I showed how from very early in the twentieth century there were many intersections between mathematical lines of argument and economic analysis. The postwar mathematization was rooted in prewar attempts by individuals like Fisher and Evans and Frisch and Hotelling to develop more rigorous modes of economic analysis. They and their intellectual progeny -Charles Roos, Trygve Haavelmo, Kenneth Arrow - were to make significant contributions in the postwar years. Similarly important was the emigration to the U.S. of refugee European economists who were mathematically or statistically sophisticated members of Rockefeller-sponsored business cycle research institutes (like Morgenstern, Wald, Tintner, Fellner, Marschak, Koopmans, et al.) The 
Econometric Society, while small in the 1930s, was nonetheless active in holding meetings, publishing articles and naming meretricious fellows. The Review of Economic Studies was developing a similar audience in Great Britain. Paul Samuelson's important prewar articles were recognized at the time as significant contributions to economic analysis. Certainly the role of wartime connections among economists and mathematicians, physicists, statisticians, and engineers created a greater awareness of the role that mathematical and statistical modeling could play in a future economics. Two recent studies (Düppe and Weintraub 2014; Weintraub 2014) have tracked the multiple ways that mathematics and economics came to be intertwined in the first postwar decade. The award of the first John Bates Clark medal to Paul Samuelson in 1947 was an emblem of the decisive turn in the mathematization of economics. This was several years before the Red Scare frenzy produced McCarthy.

Not every contribution to the growth of scientific knowledge has a specific social cause. Historians of science long ago gave up such a Marxist determinism as providing satisfying explanations for scientific discoveries and scientific change. That some uninteresting historians of economics continue to tell purely internalist stories of economic progress is no reason to tell uninteresting and unconvincing stories in which economic researchers have no agency. "McCarthyism made them do mathematics, teach it, and like it" hardly touches the larger set of personal beliefs, histories, and dreams that helped economists to shape a new professional identity in the postwar years. 


\section{References}

Amadae, S. M. (2003). Rationalizing Capitalist Democracy: The Cold War Origins of Rational Choice Liberalism. Chicago IL, University of Chicago Press.

Antonio, E. d. and D. Talbot (1964). Point of Order! New York NY, Norton.

Backhouse, R. E. (2014). Hans Apel, Samuelson's Economics, and Academic Freedom, 1950-57 (Version 2). Birmingham, UK, University of Birmingham.

Backhouse, R. E. and P. Fontaine (2014). Contested Identities: The History of Economics since 1945. A Historiography of the Modern Social Sciences. R. E. Backhouse and P. Fontaine. New York, NY, Cambridge University Press: 183-210.

Bellman, R. E. (1984). Eye of the Hurricane: An Autobiography. Hackensack, NJ, World Scientific Publishing.

Bender, T. (1997). "Politics, Intellect, and the American University, 1945-1995." Daedalus 126(1): 138.

Blaug, M. (1999). The formalist revolution or what happened to orthodox economics after World War II? From Classical Economics to the Theory of the Firm. R. E. Backhouse and J. Creedy. Cheltenham, UK, Edward Elgar. 
Brazer, M. C. (1981). The Economics Department of the University of Michigan: A Centennial Retrospective. Economics and the World Around It. S. H. Hymans. Ann Arbor, MI, The University of Michigan Press: $133-275$.

Bronfenbrenner, M. (1988). "Instead of a Philosophy of Life." The American Economist 32(2): 3-10.

Bronfenbrenner, M. (1993). Wisconsin 1947-1957: Reflections and Confessions. Economists at Wisconsin. R. J. Lampman. Madison, WI, University of Wisconsin: 130-138.

Buckley, W. F. (1951). God and Man at Yale. New York, Regnery Publishing.

Carleton, D. E. (1985). Red Scare! Right-wing Hysteria, Fifties Fanaticism, and their Legacy in Texas. Austin, TX, Texas Monthly Press.

Colander, D. C. and H. Landreth, Eds. (1996). The Coming of Keynesianism to America: conversations with the founders of Keynesian economics. . Brookfield, VT, Edward Elgar.

Duppe, T. and E. R. Weintraub (2014). Finding Equilibrium: Arrow, Debreu, McKenzie and the Problem of Scientific Credit. Princeton NJ, Princeton University Press. 
Easton, D. (1991). Political Science in the United States Past and Present. Divided Knowledge: across disciplines, across cultures. D. Easton and C. S. Schelling. Newbury Park, CA, SAGE Publications: $37-58$.

Fones-Wolf, E. A. (1994). Selling Free Enterprise: The Business Assault on Labor and Liberalism, 194560. Urbana and Chicago, IL, University of Illinois Press.

Fourcade, M. (2009). Economists and Societies. Princeton NJ, Princeton University Press.

Furner, M. (1975). Advocacy and Objectivity: A Crisis in the Professionalization of American Social Science, 1865-105. Lexington, KY, University of Kentucky Press.

Gieryn, T. F. (1999). Cultural Boundaries of Sciences: Credibility on the Line. Chicago, IL, University of Chicago Press.

Giraud, Y. (2014). Negotiating the 'Middle of the Road' Position: Paul Samuelson, MIT, and the Politics of Textbook Writing, 1945-55. MIT and the Transformation of American Economics. E. R. Weintraub. Durham, NC, Duke University Press: 134-152.

Goodwin, C. (1999). The Patrons of Economics in a Time of Transformation. From Interwar Pluralism to Postwar Neoclassicism. M. S. Morgan and M. Rutherford. Durham, NC, Duke University Press: 53-81.

Hollinger, D. A. (2002). "Religion, Ethnicity, and Politics in American Philosophy: Reflections on McCumber's Time in the Ditch." Philosophical Studies 102: 173-181.

Hutcheson, P. A. (1997). McCarthyism and the Professoriate: A Historiographic Nightmere? Higher 
Education: Handbook of Theory and Research 12. J. C. Smart and W. Tierney. New York, NY, Agathon Press (Kluwer).

Hymans, S. H., Ed. (1982). Economics and the World Aroound It. Ann Arbor MI, University of Michigan Press.

Klausner, S. Z. and V. M. Lidz, Eds. (1986). The Nationalization of the Social Sciences. Philadelphia PA, University of Pennsylvania Press.

Lazarsfeld, P. F. and W. Thielens Jr. (1958). The Academic Mind: Social Scientists in a Time of Crisis. Glencoe IL, The Free Press.

Lee, F. (2009). A History of Heterodox Economics. New York, NY, Routledge.

Maclver, R. M. (1955). Academic Freedom in Our Time. New York NY, Columbia University Press.

McCormick, C. H. (1989). This Nest of Vipers: McCarthyism and Higher Education in the Mundell Affair, 1951-52. Urbana and Chicago, IL, University of Illinois Press.

McCumber, J. (2001). Time in the Ditch: American Philosophy and the McCarthy Era. Evanston IL.

Mirowski, P. E. (2002). Machine Dreams. Cambridge, Harvard University Press.

Modigliani, F. (2001). Adventures of an Economist. NewYork NY, TEXERE LLC.

Morgan, M. and M. Rutherford, Eds. (1999). From Interwar Pluralism to Postwar Neoclassicism. 
Durham, NC, Duke University Press.

Morgan, M. S. (2003). Economics. The Cambridge History of Science, Volume 7: The Modern Social

Sciences. T. M. Porter and D. Ross. Cambridge, UK, Cambridge University Press: 275-305.

Rancan, A. (2008). Academic McCarthyism at the University of Illinois: An Integration. Working Paper, CHOPE, Duke University.

Rapoport, A. (2000). Certainties and Doubts. Montreal, Black Rose Books.

Reisch, G. A. (2005). How the Cold War Transformed the Philosophy of Science: To the Icy Slopes of Logic. New York and Cambridge, Cambridge University Press.

Schrecker, E. W. (1986). No Ivory Tower: McCarthism and the Universities. New York, NY, Oxford University Press.

Schrecker, E. (1998). Many are the Crimes: McCarthyism in America. Boston, Little, Brown and Co.

Schrecker, E. (2002). The Age of McCarthism, 2nd Edition. Boston MA, Bedford/St. Martins.

Selcraig, J. T. (1982). The Red Scare in the Midwest, 1945-1955. Ann Arbor MI, UMI Research Press.

Solberg, W. and R. Tomilson (1997). "Academic McCarthyism and Keynesian Economics: the Bowen Controversy at the University of Illinois." History of Political Economy 29(1): 55-81.

Stewart, G. R. (1950). The Year of the Oath. New York NY, Doubleday. 
Thielens, W. (1996). "McCarthyism and Academic Freedom: Why Wasn't the Damage Worse? Some Answers from the Academic Mind." William Mitchell Law Review 22.

Trilling, L. (1958). "Mind and Market in Academic Life." The Griffin 7(13): 4-17.

Weintraub, E. R. (2002). How Economics Became a Mathematical Science. Durham, NC, Duke University Press.

Weintraub, E. R., Ed. (2014). MIT and the Transformation of American Economics. Durham NC, Duke University Press. 